\title{
Post-settlement growth and mortality rates of juvenile scleractinian corals in Moorea, French Polynesia versus Trunk Reef, Australia
}

\author{
M. L. Trapon ${ }^{1, *}$, M. S. Pratchett ${ }^{1,2}$, M. Adjeroud ${ }^{3,4}$, A. S. Hoey ${ }^{1}$, A. H. Baird ${ }^{1}$ \\ ${ }^{1}$ ARC Centre of Excellence for Coral Reef Studies, James Cook University, Townsville, Queensland 4811, Australia \\ ${ }^{2}$ USR 3278 CNRS-EPHE, CRIOBE, BP 1013, 98729 Papeete, Moorea, French Polynesia \\ ${ }^{3}$ Institut de Recherche pour le Développement, Unité 227 CoRéUs2, BP A5, 98848 Nouméa Cedex, New Caledonia \\ ${ }^{4}$ Laboratoire d'Excellence 'CORAIL', 58 avenue Paul Alduy, 66860 Perpignan CEDEX, France
}

\begin{abstract}
Patterns and processes affecting juvenile scleractinian corals have received very little attention due to difficulties associated with detecting small corals on natural substrata. However, processes occurring during juvenile life stages are likely to play a strong role in population ecology. In particular, spatial differences in juvenile demographic rates may result in prominent differences in population and community structure for corals. In the present study, we compared the density, taxonomic composition, size structure, growth and mortality rates of juvenile corals $(\leq 50 \mathrm{~mm})$ and the cover and composition of adult coral assemblages among sites on Trunk Reef (central Great Barrier Reef) and Moorea (French Polynesia). There was significant regional variation in the taxonomic composition of coral assemblages within both adult and juvenile assemblages, with Pocillopora being the predominant coral genus in Moorea and Acropora at Trunk Reef. However, there were no differences in the density, growth or mortality rates of juvenile corals between Moorea and Trunk Reef. Most of the variation in these variables was evident at the small (within-reef) scale, with exposed sites having lower densities and higher rates of mortality of juvenile corals than sheltered sites at both locations. The lack of geographic variation in the density, growth and mortality rates of juvenile corals is interesting given that the cover of adult coral was 3-fold higher on Moorea (31.1\%) than Trunk Reef (10.8\%), suggesting that adult coral assemblages are structured more by differential adult mortality, larval settlement or very early post-settlement mortality (before colonies can be observed in situ), rather than demographic rates of juvenile growth or mortality.
\end{abstract}

KEY WORDS: Scleractinian corals $\cdot$ Juveniles $\cdot$ Mortality $\cdot$ Growth $\cdot$ Spatial patterns

\section{INTRODUCTION}

Scleractinian corals, like most marine invertebrates, have a bipartite life cycle in which larvae develop in the plankton before settling and attaching to the substratum. The larval stage therefore provides an important means of dispersal for sessile reef corals, enabling colonisation of new habitats, recolonisation following disturbance, and genetic exchange among subpopulations (Caley et al. 1996).
Ultimately, the distribution and abundance of larvae may also limit geographic distributions and regulate local populations of marine organisms (Hughes 1990, Cowen \& Sponaugle 2009, Weersing \& Toonen 2009). However, the abundance of new recruits (assumed to reflect variability in larval supply) often shows little or no relation to patterns of adult abundance (Bak \& Engel 1979, Rylaarsdam 1983, Fisk \& Harriott 1990, Baird \& Hughes 1997, Hughes et al. 1999, Penin et al. 2010), suggesting that spatial and temporal variation 
in recruitment has limited influence on the distribution and abundance of adult corals (Hughes et al. 1999, 2002). The effects of larval input on adult abundance may be difficult to detect because adult abundance reflects the accumulation of recruits over many successive cohorts, and infrequent years of very high recruitment might have a disproportionate influence on adult abundance (Edmunds 2000). Alternatively, extreme variability in post-settlement growth and mortality may effectively decouple relationships between recruitment rates and adult abundance (Hughes et al. 1999, 2002).

Estimates of post-settlement mortality in scleractinian corals are rare, but mortality is known to vary with size, with the smallest size class $(<10 \mathrm{~mm}$ recruits; Penin et al. 2010) experiencing up to $100 \%$ mortality within the first year (Harriott 1983, Rylaarsdam 1983, Babcock 1985, Babcock \& Mundy 1996), thereby representing a critical demographic bottleneck for coral populations (Vermeij \& Sandin 2008). For example, early post-settlement mortality in Acropora millepora, Goniastrea aspera and Platygyra sinensis was found to be $>65 \%$ during the first 8 mo after settlement (Babcock 1985). High rates of mortality may therefore have an important role in regulating the abundance and composition of adult coral assemblages (Vermeij \& Sandin 2008, RitsonWilliams et al. 2009). For post-settlement processes to influence patterns of adult abundance, there must be significant and consistent variation in growth or mortality among locations or habitats (Bak \& Engel 1979, Rylaarsdam 1983, Hixon \& Carr 1997). Studies that have explored variation in post-settlement mortality of scleractinian corals (e.g. Babcock \& Mundy 1996, Mundy \& Babcock 2000, Glassom \& Chadwick 2006, Penin et al. 2011) have detected significant spatial and/or temporal variation in rates of mortality. Nonetheless, these studies concluded that spatial variation in abundance of corals is established mostly at settlement, due to large-scale variation in larval supply (Glassom \& Chadwick 2006) or finescale settlement preferences of coral larvae (Babcock \& Mundy 1996, Mundy \& Babcock 2000). However, large-scale differences in demographic rates (growth and mortality) for early post-settlement coral stage or 'coral recruits' (i.e. individuals invisible to the naked eye on the substrate, size $<10 \mathrm{~mm}$ ), and later post-settlement stage or 'juvenile corals' (i.e. visible on the substrate, size $>10 \mathrm{~mm}$; see Penin et al. 2010), may contribute to geographic variation in abundance and/or resilience of coral assemblages (Sammarco 1985, Hughes et al. 1999, Wilson \& Harrison 2005, Roff \& Mumby 2012).
Coral populations show high spatial heterogeneity in abundance and taxonomic composition across a range of scales, reflecting variation in biotic and abiotic processes acting on the different life stages (Connolly et al. 2005, Cornell et al. 2007, Hughes et al. 2012). In particular, the supply of coral larvae, their successful settlement, and subsequent survival and growth can have a marked influence on local population structure. These processes are expected to differ greatly across geographic scales given the dissimilarities in adult coral assemblages, local hydrodynamics, disturbances history, competition, and sources of predation (e.g. sea star, fish, sea urchin and gastropod communities) at such scales (Connell et al. 1997, Hughes et al. 2000). On the Great Barrier Reef (GBR), settlement rates of corals have been shown to be much lower on southernmost reefs (e.g. Heron Island) compared to northern reefs (e.g. Lizard Island), whereas adult coral cover did not vary over this scale (Hughes et al. 1999). The discrepancy between these 2 life stages has been attributed to large-scale differences in underlying population dynamics (Hughes et al. 1999), whereby regional differences in post-settlement mortality can compensate for marked differences in settlement rates.

Few studies have specifically quantified postsettlement growth and mortality of juvenile corals, partly due to the effort required. To date, geographical variation in the status of coral reefs and particularly coral cover and composition is mostly attributed to differences in disturbance regimes and rates of adult mortality (Ruiz-Zárate \& Arias-González 2004). It is possible, however, that there are inherent differences in key demographic processes, such as postsettlement growth and mortality of juvenile corals, that may greatly influence the resilience of coral populations and communities. The purpose of the present study was to compare the density, taxonomic composition, growth and mortality of juvenile scleractinian corals between Moorea, French Polynesia and Trunk Reef, central GBR, Australia. Juveniles were defined as colonies visible to the naked eye with a maximum diameter $\leq 50 \mathrm{~mm}$ (sensu Rylaarsdam 1983, Miller et al. 2000, Penin et al. 2007, 2010, Hoey et al. 2011). Earlier studies on settlement rates on the reef crest at Moorea ( 40 recruits $\mathrm{m}^{-2} \mathrm{yr}^{-1}$; Adjeroud et al. 2007) revealed that settlement rates were an order of magnitude lower than on the central GBR mid-shelf reef crest (approx. 200 to 700 recruits $\mathrm{m}^{-2} \mathrm{yr}^{-1}$; Hughes et al. 1999), despite having similar cover of adult corals (Adjeroud et al. 2007). Comparisons between French Polynesia and Australia's GBR are intended to test whether post-settlement pro- 
cesses should be considered in ongoing studies to understand regional differences in the vulnerability and resilience of coral assemblages (Wilkinson 2004).

\section{MATERIALS AND METHODS}

\section{Field sampling}

Growth and mortality of juvenile corals were quantified at Moorea $\left(17^{\circ} 29^{\prime} \mathrm{S}, 149^{\circ} 5^{\prime} \mathrm{W}\right)$ in the Society Islands, French Polynesia, and at Trunk Reef (18 $17^{\prime} \mathrm{S}$, $146^{\circ} 5^{\prime} \mathrm{E}$ ), central GBR, Australia (see Fig. 6). These 2 locations are at equivalent latitudes, but there are significant and important differences in the environmental settings. Moorea is a large volcanic island (ca. $134 \mathrm{~km}^{2}$ ) surrounded by a narrow reef (ca. $49 \mathrm{~km}^{2}$ ), which can be divided into 3 distinct habitats: (1) the fringing reef, separated by a sandy channel, to (2) the barrier reef flat, separated by a reef crest, to (3) the barrier reef slope. The north coast of Moorea is subject to moderate swell during the summer (November to April), whereas the west coast is exposed to highamplitude swell throughout the year (Adjeroud et al. 2007). Reefs in Moorea have been subjected to several large-scale disturbances over the past 3 decades (Trapon et al. 2011), which have caused dramatic shifts in assemblage structure and loss of total coral cover (Berumen \& Pratchett 2006, Pratchett et al. 2011, Kayal et al. 2012).

Trunk Reef is a large mid-shelf reef in the central GBR (ca. $125 \mathrm{~km}^{2}$ ), located approximately $58 \mathrm{~km}$ from the mainland coast. Trunk Reef has welldeveloped continuous reef along the relatively exposed east, south and western margins, partially enclosing a large shallow lagoon. Trunk Reef is part of an extensive complex of reefs, with $<2 \mathrm{~km}$ to the adjacent reef (Bramble Reef). These reefs were subject to fairly extensive bleaching in 2001/2002, which, combined with outbreaks of Acanthaster planci, reduced coral cover to $<5 \%$ on the reef crest and down to a depth of 6 to $8 \mathrm{~m}$ (Pratchett et al. 2006), but there was strong recovery in the aftermath of these disturbances (Linares et al. 2011).

Sampling was conducted in 2003 at Moorea and in 2009 at Trunk Reef, which corresponded to years of maximum coral cover at each of these locations over the last decade (Linares et al. 2011, Trapon et al. 2011). At each location, sampling was undertaken at 3 sites on the reef crest habitat, at about 4 to $6 \mathrm{~m}$ depth. At Moorea, all sampling was conducted on the outer reef crest, with 2 sites (Tiahura and Vaipahu) situated on the north coast, and 1 site (Haapiti) on the west coast. The west coast has the greatest exposure to prevailing trade winds, but reefs on the north coast are subject to strong swells mostly in the summer months. At Trunk Reef, 2 sites were surveyed on the south ('South') and southeast reef crest ('East'), which are directly exposed to prevailing winds and waves. The third site was located on the southwest reef crest ('West'), which is obliquely exposed to the trade winds. At each site, 3 permanent transects (10 m each) were established, delineated using steel pegs hammered into the substratum at either end of the transect. The transects were orientated parallel to depth contours, with a minimum of $3 \mathrm{~m}$ separating adjacent transects. Juvenile corals ( $\leq 50 \mathrm{~mm}$ diameter) were surveyed within 5 replicate $1 \mathrm{~m}^{2}$ quadrats (non-adjacent), initially positioned randomly along the transect line. Colonies $\leq 50 \mathrm{~mm}$ are likely to be up to $34 \mathrm{mo}$ old based on currently available growth estimates (see Babcock et al. 2003), and are likely to be non-reproductive according to minimum reproduction size, especially for the most common genera Acropora, Pocillopora and Porites. Collectively, these genera accounted for $77.7 \%$ and $91.6 \%$ of the juvenile coral assemblage in Moorea and Trunk Reef, respectively. However, this maximum size might not be appropriate for a few taxa such as Favia sp. that can become sexually mature at sizes as small as $20 \mathrm{~mm}$ (Miller et al. 2000).

To maximise detection of juvenile corals, the $1 \mathrm{~m}^{2}$ replicate quadrats were divided into a $10 \times 10$ grid using strings placed at $10 \mathrm{~cm}$ intervals along the vertical and horizontal axes. The resulting 100 squares $\left(10 \mathrm{~cm}^{2}\right.$ each) were systematically inspected for the presence of juvenile corals. All juvenile corals detected during Census 1 were identified to the highest possible taxonomic level (mostly genus), and the maximum diameter was measured to the nearest millimetre using calipers. The size and condition of each coral was then assessed after 6 to 8 mo, during Census 2 . The total observation period ( 6 to $8 \mathrm{mo}$ ) is not ideal, because it does not capture total annual mortality, but corresponds closely with several other studies of post-settlement growth and mortality for scleractinian corals (e.g. Babcock \& Mundy 1996, Box \& Mumby 2007). Colonies that were experiencing partial mortality and thus a decrease in size were characterised by a withdrawal of the tissue that was no longer extending to the base of the skeleton (Edmunds 2007). Realised growth rates, accounting for both colonies that increase and colonies that decrease in mean diameter, were expressed as mm $\mathrm{mo}^{-1}$. Potential growth rates, i.e. colonies that grew $\geq 0 \mathrm{~mm} \mathrm{mo}^{-1}$ (following Edmunds 2007), were also calculated to test for any differences with realised 
growth rates. Mortality rates were expressed as the proportion of individuals that died or were missing on the next census.

Percentage cover of scleractinian corals was recorded at each site within each location using pointintercept methods, whereby coral or substratum types were recorded directly beneath a minimum of 500 uniformly spaced points per site. In the present study, we distinguished 3 major adult coral genera, Acropora, Pocillopora, and Porites, that accounted for 76.0 and $94.2 \%$ of the adult coral assemblage in Moorea and Trunk Reef, respectively. All other coral genera were pooled into a single category of 'other'.

\section{Analyses}

Abundance of both juvenile and adult corals (all taxa combined) were compared between the 2 geographic locations (Moorea and Trunk Reef), as well as among sites (3 sites per location) using a 2-factor ANOVA. Differences in the taxonomic composition of juvenile and adult coral assemblages (Acropora, Pocillopora, Porites and 'other' corals category) were compared between locations and among sites using a 2-factor multivariate ANOVA (MANOVA). Although quadrats were arranged along transects, transect was not considered as a level in these analyses. The number of juvenile corals per quadrat (both collectively and the main taxa independently) was logtransformed, and percent cover of adult coral was arcsine-square-root-transformed to meet the parametric assumptions.

Monthly growth rates or 'linear extensions' (mm $\mathrm{mo}^{-1}$ ) were calculated by subtracting the maximum diameter at Census 2 from the maximum diameter at Census 1, divided by the number of months between censuses, and monthly mortality rates were calculated by dividing the number of dead juveniles by the number of months between Census 2 and Census 1. Monthly growth rates or 'linear extensions' were log-transformed, and monthly mortality rates were arcsine-square-root-transformed to improve normality and homoscedasticity. A 1-factor ANOVA was used to determine whether realised growth rates differed from potential growth rates, which could indicate whether partial mortality occurred between the 2 censuses. Realised monthly growth and monthly mortality of juvenile corals was compared among the 3 main genera (Acropora, Pocillopora and Porites), between 2 geographic locations (Moorea vs. Trunk Reef), and among sites (3 sites nested within each location) using a 3-factor ANOVA.
Juvenile corals were then separated into 5 size classes: <10, 10-19, 20-29, 30-39 and 40-50 mm. A chi-squared contingency table was used to compare juveniles' size structure between locations for each of the 3 main genera, Acropora, Pocillopora and Porites. Sites within each location were pooled due to the limited number of individuals within some size classes and/or genera. In addition, monthly mortality and realised monthly growth rates were compared among the 5 size classes and between the 2 locations for each genus using a series of 2-factor ANOVAs. Again, sites within each location were pooled to increase power. Monthly mortality rates were arcsinesquare-root-transformed, while no transformations were necessary for monthly growth rates. However, due to the lack of Porites juveniles in Moorea (i.e. $\leq 40 \mathrm{~mm}$ ), the 2 larger size classes (30-39 and 40-50 $\mathrm{mm}$ ) were pooled into 1 size class $(30-50 \mathrm{~mm})$. Furthermore, due to the absence of small Pocillopora (i.e. $<10 \mathrm{~mm}$ ) at Trunk Reef, the 2 smaller size classes (0-9 and 10-19 $\mathrm{mm}$ ) were pooled $(0-19 \mathrm{~mm})$.

Finally, a series of correlations were used to determine if: (1) the mortality rates of juvenile corals were related to initial juvenile density, and (2) the density of juvenile corals was related to the cover of adult corals at each location. The correlations between mortality rates and juvenile coral density were based on individual quadrats, with data pooled across the 3 sites within each location (Moorea: $\mathrm{n}=45$, Trunk Reef: $\mathrm{n}=45$ ). Separate analyses were performed for all juvenile corals collectively and the 3 main genera independently (Acropora, Pocillopora and Porites). As total coral cover was not quantified within individual quadrats, the relationship between adult coral cover and the density of juvenile corals was examined at the scale of transects ( $\mathrm{n}=9$ transects per location). Separate analyses were performed for all corals collectively, and the 3 main genera independently (Acropora, Pocillopora and Porites).

\section{RESULTS}

\section{Abundance and composition of juvenile corals}

A total of 643 juvenile corals were recorded across both study locations (296 at Moorea; 347 at Trunk Reef), corresponding to a mean $( \pm \mathrm{SE})$ density of $7.14 \pm 0.42$ juveniles $\mathrm{m}^{-2}$. The overall density of juvenile corals was not significantly different between locations (Moorea: $6.57 \pm 0.52$ ind. $\mathrm{m}^{-2}$; Trunk Reef: $7.71 \pm 0.64$ ind. $\left.\mathrm{m}^{-2}{ }_{;} F_{1,4}=0.395, \mathrm{p}=0.564\right)$, but did differ among sites within reefs $\left(F_{4,84}=7.304, \mathrm{p}<\right.$ 
0.001). Most notably, the density of juvenile corals at the most exposed site in Moorea, Haapiti (3.80 \pm 0.48 ind. $\mathrm{m}^{-2}$ ), was much lower when compared to sites on the northern coast, Vaipahu $(8.46 \pm 0.71$ ind. $\left.\mathrm{m}^{-2}\right)$ and Tiahura $\left(7.47 \pm 0.98\right.$ ind. $\left.\mathrm{m}^{-2}\right)$. On Trunk Reef, the density of juvenile corals was highest at the West site $\left(9.20 \pm 1.64\right.$ ind. $\left.\mathrm{m}^{-2}\right)$ compared to the South site $\left(7.53 \pm 0.58\right.$ ind $\left.\mathrm{m}^{-2}\right)$ and East site $(6.40 \pm$ 0.76 ind. $\mathrm{m}^{-2}$ ).

Juvenile coral assemblages at both Moorea and Trunk Reef were dominated by the genera Acropora, Pocillopora and Porites. Collectively, these 3 genera accounted for $77.7 \%$ (230/296) of all juvenile corals recorded on the reef crest at Moorea, and $91.6 \%$ (318/347) of juvenile corals at Trunk Reef. Other, less abundant genera recorded at Moorea were Acanthastrea (0.3\%), Montipora (11.9\%), Montastrea (6.4\%) and Leptastrea (3.7\%), and at Trunk Reef Cyphastrea (0.9\%), Echinopora (0.3\%), Favia (0.9\%), Favites $(1.5 \%)$, Hydnophora (0.3\%), Montipora (1.2\%), Montastrea $(0.9 \%)$, Leptastrea $(0.6 \%)$, Pectinia $(0.3 \%)$, Stylocoen $(0.6 \%)$ and Stylophora $(0.4 \%)$. The relative abundance of the 3 main genera and the remaining genera pooled together differed significantly among locations (MANOVA: $F_{4,81}=55.55, \mathrm{p}<$ 0.001) and among sites nested within locations (MANOVA: $F_{16,336}=3.125, \mathrm{p}<0.001$ ). Juvenile coral assemblages on Trunk Reef were dominated by Acropora (39.2\%) and Porites (40.9\%), whereas Pocillopora was the predominant genus at all sites in

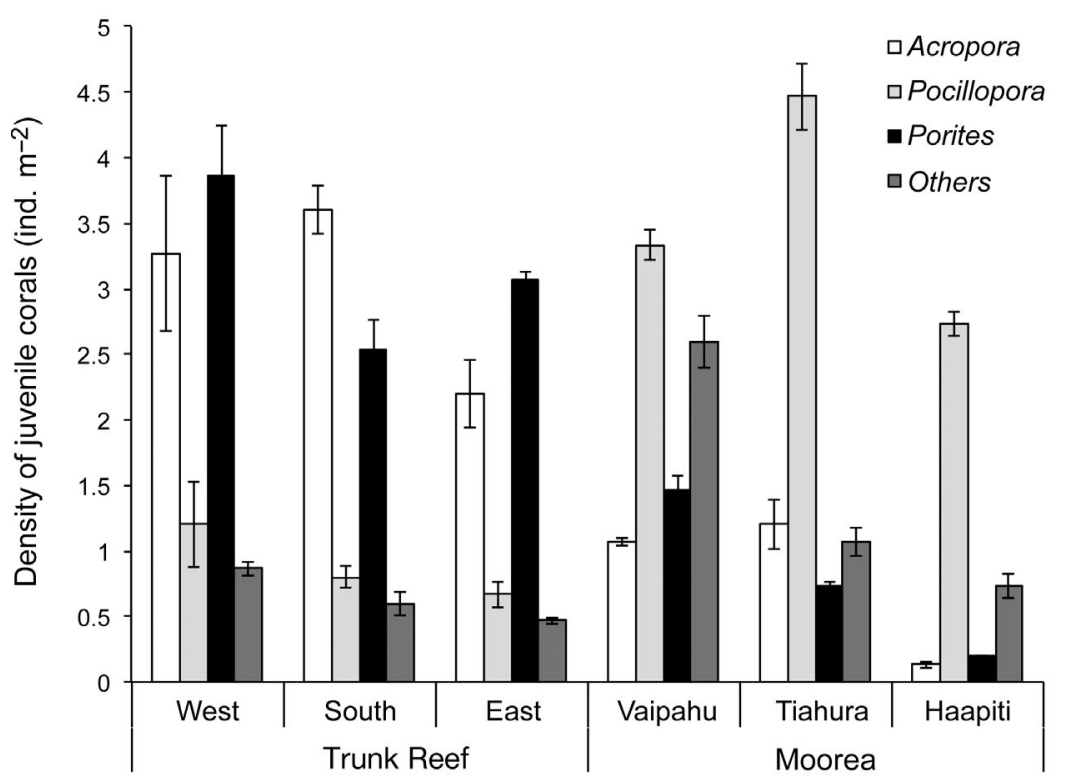

Fig. 1. Density of juvenile scleractinian corals among 3 reef crest sites within Trunk Reef and Moorea. Means are based on 15 quadrats $\left(1 \mathrm{~m}^{2}\right)$ at each site. Error bars represent \pm SE
Moorea (53.4\%; Fig. 1). Variation among sites was most pronounced in Moorea, with Acropora and Porites being more abundant at Vaipahu and Tiahura than at Haapiti (Fig. 1). Conversely, Pocillopora was more abundant at Haapiti $(71.2 \%)$ than at Vaipahu $(39.8 \%)$ and Tiahura (59.8\%; Fig. 1). Densities of 'other' coral genera (in this case, mostly Montipora and Montastrea) were also much higher at Vaipahu $\left(2.6 \pm 0.2\right.$ juveniles $\left.\mathrm{m}^{-2}\right)$ compared to all other sites in Moorea and at Trunk Reef.

\section{Juvenile coral mortality}

A total of 175 (out of 643) juvenile corals were dead or could not be found after 6 to $8 \mathrm{mo}$ at Moorea and Trunk Reef, representing an average $( \pm \mathrm{SE})$ monthly mortality of $4.41 \pm 0.51 \%$. This corresponds to an annual average $( \pm \mathrm{SE})$ mortality rate of $52.92 \pm$ $6.15 \%$. Overall, monthly mortality rates of juvenile corals did not differ between the 2 locations or among the 3 main genera; however, monthly mortality differed among sites within locations (Table 1a, Fig. 2). Within each location, mortality rates were higher at the sites directly exposed to the prevailing wind and waves. Mortality at Haapiti $\left(7.40 \% \mathrm{mo}^{-1}\right)$ in Moorea was 2-fold higher than at Vaipahu $(3.80 \%$ $\mathrm{mo}^{-1}$ ) and almost 4 -fold higher than at Tiahura $(2.0 \%$ $\mathrm{mo}^{-1}$ ). On Trunk Reef, mortality of juvenile corals on the relatively sheltered West site $(3.40 \%)$ was approximately 1.5 -fold lower than at the more exposed South (4.85\%) and East sites (5.30\%; Fig. 2). Lastly, there was limited evidence of densitydependent mortality (Fig. 3). For Porites, monthly mortality rates for juveniles positively correlated with initial densities recorded at Trunk Reef (Table 2, Fig. 3h). For all taxa and locations, there was no relationship between initial density of juvenile corals and local mortality rates within quadrats (Table 2, Fig. 3a-g).

\section{Juvenile coral growth}

For the 468 (out of 643) juvenile corals that were still alive after 6 to $8 \mathrm{mo}$, absolute growth rates (specifically, change in maximum diameter) ranged from -4.2 up to $5.0 \mathrm{~mm} \mathrm{mo}^{-1}$. Only 23 (out of 468) juveniles exhib- 
Table 1. Three-factor ANOVAs comparing (a) mortality and (b) growth of juvenile scleractinian corals $(\leq 50 \mathrm{~mm})$ among genera, locations (Trunk Reef and Moorea) and 3 sites within each location. Mortality rates were arcsine-transformed, and monthly growth was log-transformed to meet the parametric assumption. Significant results $(p<0.05)$ are in bold

\begin{tabular}{|lccccc|}
\hline Source & SS & df & MS & $F$ & $\mathrm{p}$ \\
\hline (a) Mortality & & & & & \\
Genus & 0.034 & 2 & 0.017 & 1.559 & 0.236 \\
Location & 0.051 & 1 & 0.051 & 0.89 & 0.394 \\
Site (Location) & 0.245 & 4 & 0.061 & 6.531 & $\mathbf{0 . 0 0 6}$ \\
Genus $\times$ Location & 0.026 & 2 & 0.013 & 1.194 & 0.325 \\
Genus $\times$ Site (Location) & 0.067 & 8 & 0.008 & 0.354 & 0.943 \\
& & & & & \\
(b) Growth & & & & & \\
Genus & 0.407 & 2 & 0.204 & 5.319 & $\mathbf{0 . 0 0 5}$ \\
Location & 0.264 & 1 & 0.264 & 3.774 & 0.077 \\
Site (Location) & 0.282 & 4 & 0.07 & 3.769 & $\mathbf{0 . 0 0 6}$ \\
Genus $\times$ Location & 0.04 & 2 & 0.02 & 0.524 & 0.592 \\
Genus $\times$ Site (Location) & 0.032 & 8 & 0.004 & 0.058 & 0.999 \\
\hline
\end{tabular}

ited net negative growth, reflective of some partial mortality, and a further 5 individuals (mostly Porites) exhibited no change in diameter over the course of the study. Realised growth (mean $\pm \mathrm{SE}$ ) did not differ from potential growth at Moorea (1.57 \pm 0.07 vs. 1.65 $\pm 0.06 \mathrm{~mm} \mathrm{mo}^{-1} ; F_{1,469}=0.564, \mathrm{p}=0.453$ ) or at Trunk Reef $\left(1.55 \pm 0.08\right.$ vs. $1.75 \pm 0.07 \mathrm{~mm} \mathrm{mo}^{-1} ; F_{1,440}=$ $3.492, \mathrm{p}=0.062$ ). Realised growth rates did not vary

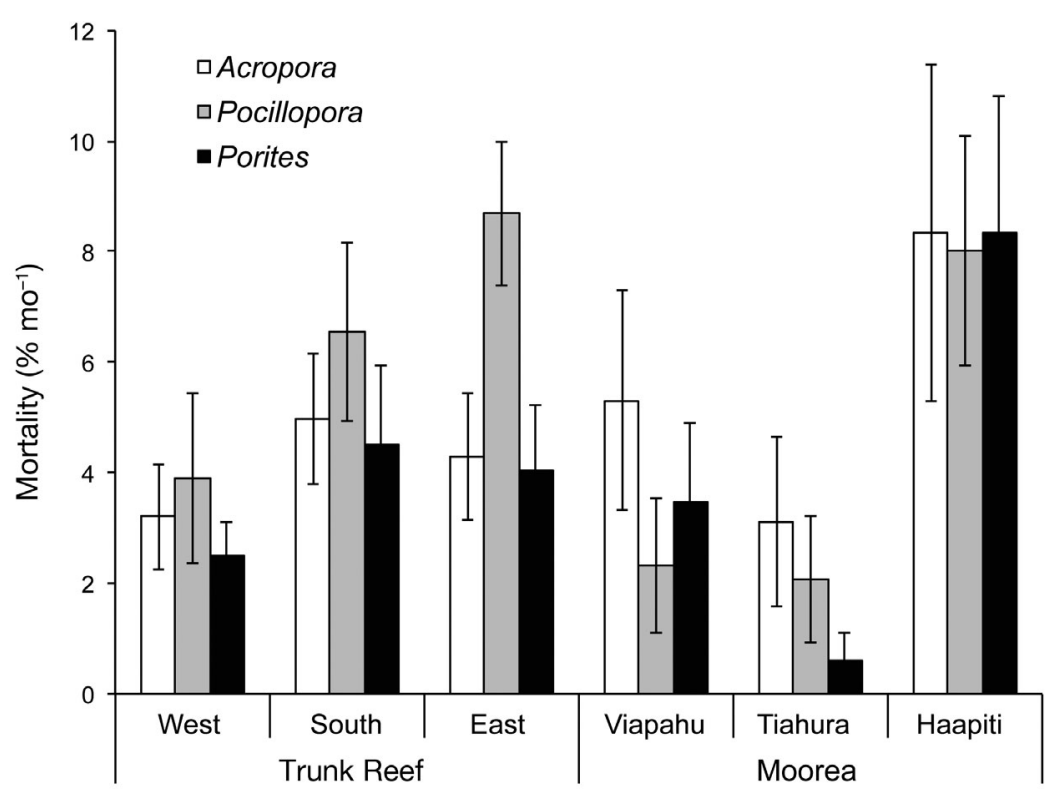

Fig. 2. Monthly mortality rates of juvenile scleractinian corals (the 3 dominant genera) among 3 reef crest sites within Trunk Reef and Moorea. Means are based on 15 quadrats $\left(1 \mathrm{~m}^{2}\right)$ at each site. Error bars represent $\pm \mathrm{SE}$ between locations, but did vary significantly among genera and among sites within locations (Table $1 \mathrm{~b}$, Fig. 4). Post hoc tests revealed that linear extension of juvenile Acropora $\left(1.98 \pm 0.11 \mathrm{~mm} \mathrm{mo}^{-1}\right)$ was higher than that of Pocillopora $\left(1.69 \pm 0.08 \mathrm{~mm} \mathrm{mo}^{-1}\right)$, which in turn was higher than that of Porites $(1.23 \pm$ $0.09 \mathrm{~mm} \mathrm{mo}^{-1}$ ). Within Moorea, realised growth rates were highest at Haapiti, the exposed site $(2.08 \pm$ $\left.0.17 \mathrm{~mm} \mathrm{mo}^{-1}\right)$, compared to Tiahura $(1.70 \pm 0.09 \mathrm{~mm}$ $\left.\mathrm{mo}^{-1}\right)$ and Vaipahu $\left(1.31 \pm 0.10 \mathrm{~mm} \mathrm{mo}^{-1}\right)$. On Trunk Reef, realised growth rates were marginally higher at the southernmost (i.e. South) site $(1.72 \pm 0.12 \mathrm{~mm}$ $\mathrm{mo}^{-1}$ ) compared to the East and West sites (1.50 \pm 0.16 and $1.45 \pm 0.12 \mathrm{~mm} \mathrm{mo}^{-1}$, respectively).

\section{Juvenile coral size structure}

The size structure of Acropora juvenile corals differed among locations $\left(\chi^{2}=23.4, \mathrm{df}=4, \mathrm{p}<0.001\right.$; Fig. 5a), with a higher proportion of smaller juveniles (10-19 mm) at Moorea (16/36 ind.) compared to Trunk Reef (23/136 ind.). Conversely, there was a higher proportion of larger juveniles (30-39 mm) at Trunk Reef (39/136 ind.) than at Moorea (4/36 ind.; Fig. 5a). Porites juvenile corals' size structure also varied among locations $\left(\chi^{2}=13.9, \mathrm{df}=4, \mathrm{p}<0.01\right.$; Fig. 5c), with also a higher proportion of smaller juveniles (10-19 mm) at Moorea (14/36 ind.) compared to Trunk Reef (32/142 ind.; Fig. 5c), and a higher proportion of 30-39 mm sized juveniles at Trunk Reef (44/142 ind.) compared to Moorea (7/36 ind.). There was no variation in the size structure of Pocillopora juveniles $\left(\chi^{2}=3.6, \mathrm{df}=4, \mathrm{p}=\right.$ 0.46 ; Fig. $5 b)$. Monthly mortality rates of Acropora corals differed among the 5 size classes (Table 3) and Fisher's least significant difference post hoc test revealed that mortality rates in the size class 10-19 mm was significantly higher than the ones from the 2 larger size classes, 30-39 and 40$50 \mathrm{~mm}$ (Fig. 5d). However, monthly growth rates of juvenile Acropora did not differ among the 5 size classes (Table 4, Fig. 5g). Furthermore, monthly mortality rates and monthly growth rates of Pocillopora and Porites juveniles did not vary significantly among size classes or locations (Tables 3 \& 4, Fig. 5e,h \& 5f,i respectively). 


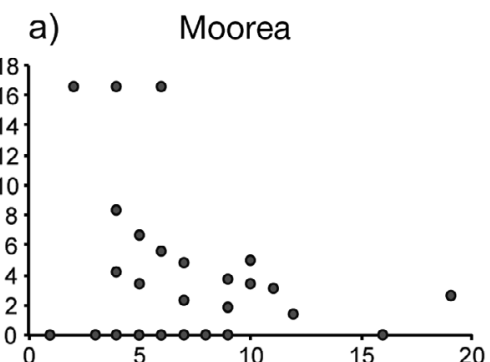

c)

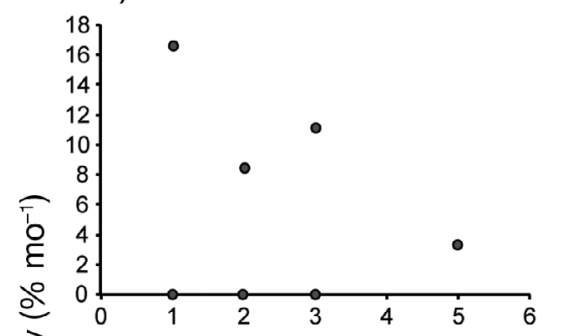

e)

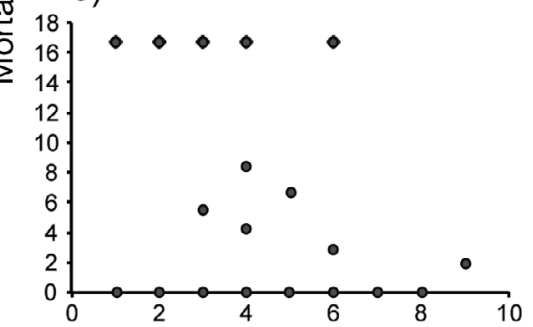

g)

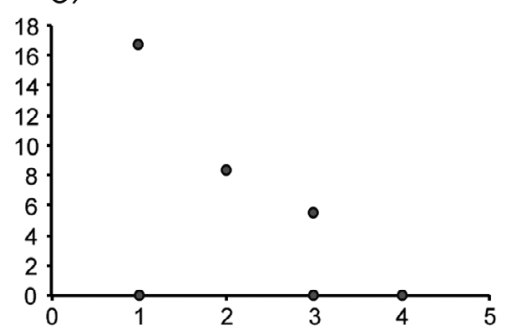

Initial juvenile density (ind. $\mathrm{m}^{-2}$ )

Fig. 3. Relationship between monthly mortality rates of juvenile coral and mean initial juvenile densities on the reef crest of Moorea and Trunk Reef, for (a,b) total corals, (c,d) Acropora, (e,f) Pocillopora and (g,h) Porites. Analyses are based on monthly mortality rates and mean juvenile densities per transect (initially $\mathrm{n}=45$ for each location). Note that the number of quadrats varies, as juvenile corals were not always observed in each quadrat. The solid line (h) represents a significant correlation

$1.3 \%)$. Within each location, coral cover was lowest within the most exposed sites. On Moorea, coral cover was the lowest at Haapiti $(15.0 \pm 2.9 \%)$ compared to Tiahura $(46.2 \pm 3.6 \%)$ and Viapahu $(32.0 \pm$ $3.6 \%$; Fig. 6). Similarly, on Trunk Reef, adult coral cover was lower at the East site $(6.2 \pm 1.1 \%)$ compared to the South and West sites $(13.9 \pm$ $2.3 \%$ and $12.3 \pm 2.6 \%$, respectively). The taxonomic composition of adult corals differed between locations (MANOVA: $F_{4,51}=76.22$, $\mathrm{p}<0.001$ ), with coral assemblages dominated by Pocillopora in Moorea $\quad(49.3 \%$ relative abundance) and by Acropora at Trunk Reef $(74.3 \%$ relative abundance; Fig. 6). There was also significant variation in the composition of adult coral assemblages among sites within each location (MANOVA: $\left.F_{16,216}=3.01, \mathrm{p}<0.001\right)$. On Moorea, Porites was relatively more abundant on the most exposed site, Haapiti (24\%), than Tiahura (16\%) and Viapahu (12\%; Fig. 6). On Trunk Reef, Acropora and Pocillopora were relatively less abundant and Porites and 'other' coral genera were relatively more abundant at the exposed site (East) than the South and West sites (Fig. 6). Adult coral cover pooled across all taxa was positively correlated with total juveniles' densities at the transect scale at Moorea (Table 5, Fig. 7a) only. However, there was no significant relationship when examining each taxon separately (Table 5, Fig. $7 \mathrm{c}-\mathrm{h}$ ) or for total coral cover against total juvenile densities at Trunk Reef (Fig. 7b).

\section{DISCUSSION}

The cover of adult corals varied significantly between locations $\left(F_{1,4}=52.8, \mathrm{p}<0.001\right)$ and among sites within each location $\left(F_{4,54}=7.1, \mathrm{p}<0.001\right)$. Overall, the cover of adult corals was almost 3-fold greater on Moorea $(31.1 \pm 3.8 \%)$ than on Trunk Reef $(10.8 \pm$
The present study revealed significant differences in the taxonomic structure of juvenile coral $(\leq 50 \mathrm{~mm})$ assemblages between Moorea and Trunk Reef, consistent with observed adult coral assemblages at each location. Juvenile and adult coral assemblages are 
Table 2. Relationship between monthly mortality of juvenile corals and initial juvenile densities (Census 1) at Moorea and Trunk Reef. Pearson's correlation coefficients (r) are given for correlations for all coral taxa collectively (i.e. total juvenile monthly mortality vs. total juvenile density), and the 3 most abundant genera independently (e.g. Acropora monthly mortality vs. juvenile Acropora density). Correlations are based on monthly mortality rates and mean initial juvenile densities per quadrat $(n=45)$. Note that the number of quadrats varies, as juvenile corals were not always observed in each quadrat. Significant results $(p<0.05)$ are in bold

\begin{tabular}{|lrcc|}
\hline & $\mathrm{r}$ & $\mathrm{n}$ & $\mathrm{p}$ \\
\hline Moorea & & & \\
Total juvenile coral & -0.085 & 44 & 0.584 \\
Acropora & -0.001 & 23 & 0.995 \\
Pocillopora & 0.175 & 43 & 0.704 \\
Porites & -0.207 & 24 & 0.414 \\
Trunk Reef & & & \\
Total juvenile coral & -0.026 & 45 & 0.868 \\
Acropora & -0.156 & 41 & 0.329 \\
Pocillopora & -0.117 & 20 & 0.622 \\
Porites & 0.541 & 45 & $\mathbf{0 . 0 0 0}$ \\
\hline
\end{tabular}

dominated by Acropora sp. on Trunk Reef (Linares et al. 2011, Trapon et al. 2013, the present study), and by Pocillopora sp. on Moorea (Adjeroud et al. 2007, Pratchett et al. 2011, present study). However, we did not find any differences in overall densities, or average rates of growth and mortality of juvenile corals between the 2 geographic locations. Furthermore, previous estimates of coral settlement suggest that it

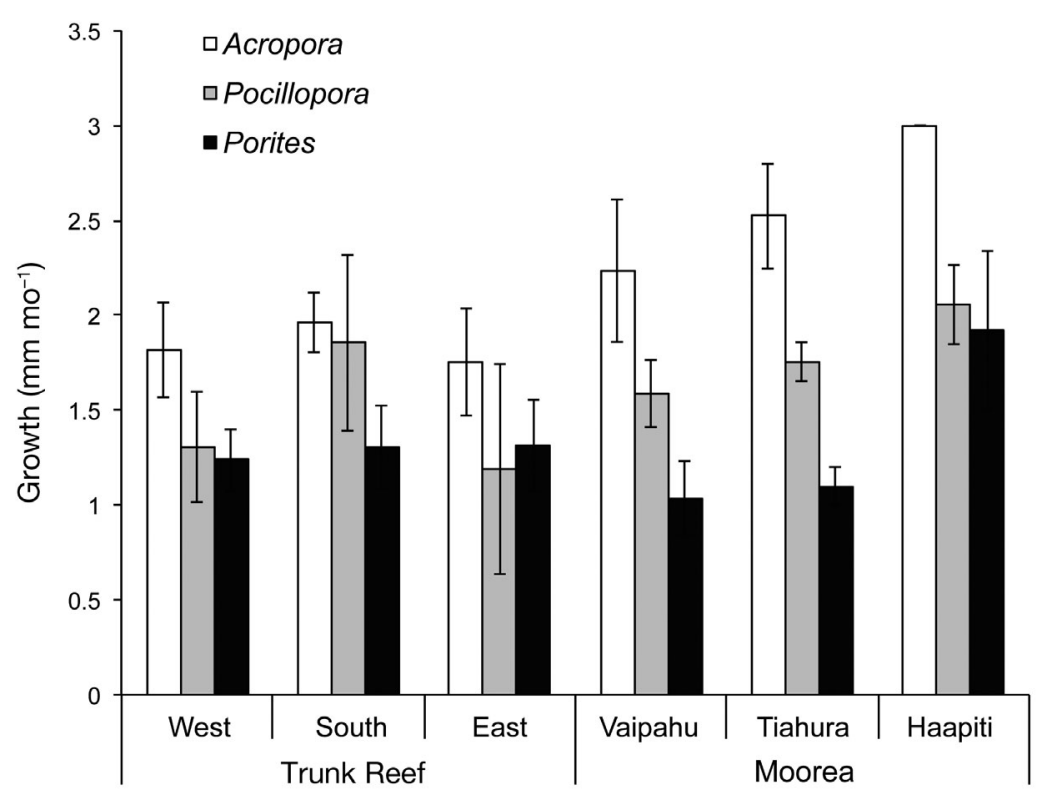

Fig. 4. Monthly growth of juvenile scleractinian corals among 3 reef crest sites within Trunk Reef and Moorea. Growth is expressed as the linear increase in maximum diameter and is shown for the 3 dominant genera. Means are based on 15 quadrats $\left(1 \mathrm{~m}^{2}\right)$ at each site. Error bars represent $\pm \mathrm{SE}$ is much lower on Moorea ( 40 recruits $\mathrm{m}^{-2} \mathrm{yr}^{-1}$; Adjeroud et al. 2007) than on central GBR mid-shelf reefs, including Trunk Reef (approx. 200 to 700 recruits $\mathrm{m}^{-2} \mathrm{yr}^{-1}$; Hughes et al. 1999). If these estimates are broadly representative of settlement rates at these locations, the similar densities of juvenile corals in the present study suggests that rates of early postsettlement mortality (i.e. before becoming visible to the naked eye at approximately $10 \mathrm{~mm}$ size; Penin et al. 2010) were lower in Moorea, and may compensate, at least to some extent, for the reduced larval supply at this location compared to Trunk Reef. Alternatively, the similar densities of juvenile corals at the 2 locations may reflect a marked decline in larval supply and/or settlement rates in the central GBR compared to rates measured by Hughes et al. (1999, 2000) over a decade ago. However, determining the relative importance of larval supply and early postsettlement mortality in shaping juvenile coral populations at these 2 locations is difficult in the absence of recent and comparable estimates of coral settlement.

Despite systematic and focused sampling for juvenile corals, the minimum size deteced on natural substratum was $5 \mathrm{~mm}$, which is substantially larger than the mean size at settlement for scleractinian corals (see Babcock et al. 2003). Therefore, we almost certainly underestimated local densities of newly settled corals in the size class $<10 \mathrm{~mm}$, and have not fully captured rates of mortality that occur within the smallest size class. Corals are known to suffer high mortality within the first weeks to months after settlement (Babcock 1985, Wilson \& Harrison 2005), and much of this mortality has been attributed to incidental predation by scraping and excavating parrotfishes (Rotjan \& Lewis 2008, Penin et al. 2010, 2011, Trapon et al. 2013). Interestingly, published estimates of abundance and biomass of parrotfishes, especially the larger excavating species, are considerably greater on the GBR than in Moorea (Bellwood et al. 2003, 2012, Hoey \& Bellwood 2008, Adam et al. 2011). However, the lack of variation in mortality of juvenile corals between Moorea and Trunk Reef suggests that such differences in parrotfish assemblages may be having limited effects on the mortality rates of later-stage (i.e. $\geq 10 \mathrm{~mm}$ ) juvenile corals. There was, however, significant variation in mortality rates among size classes of 

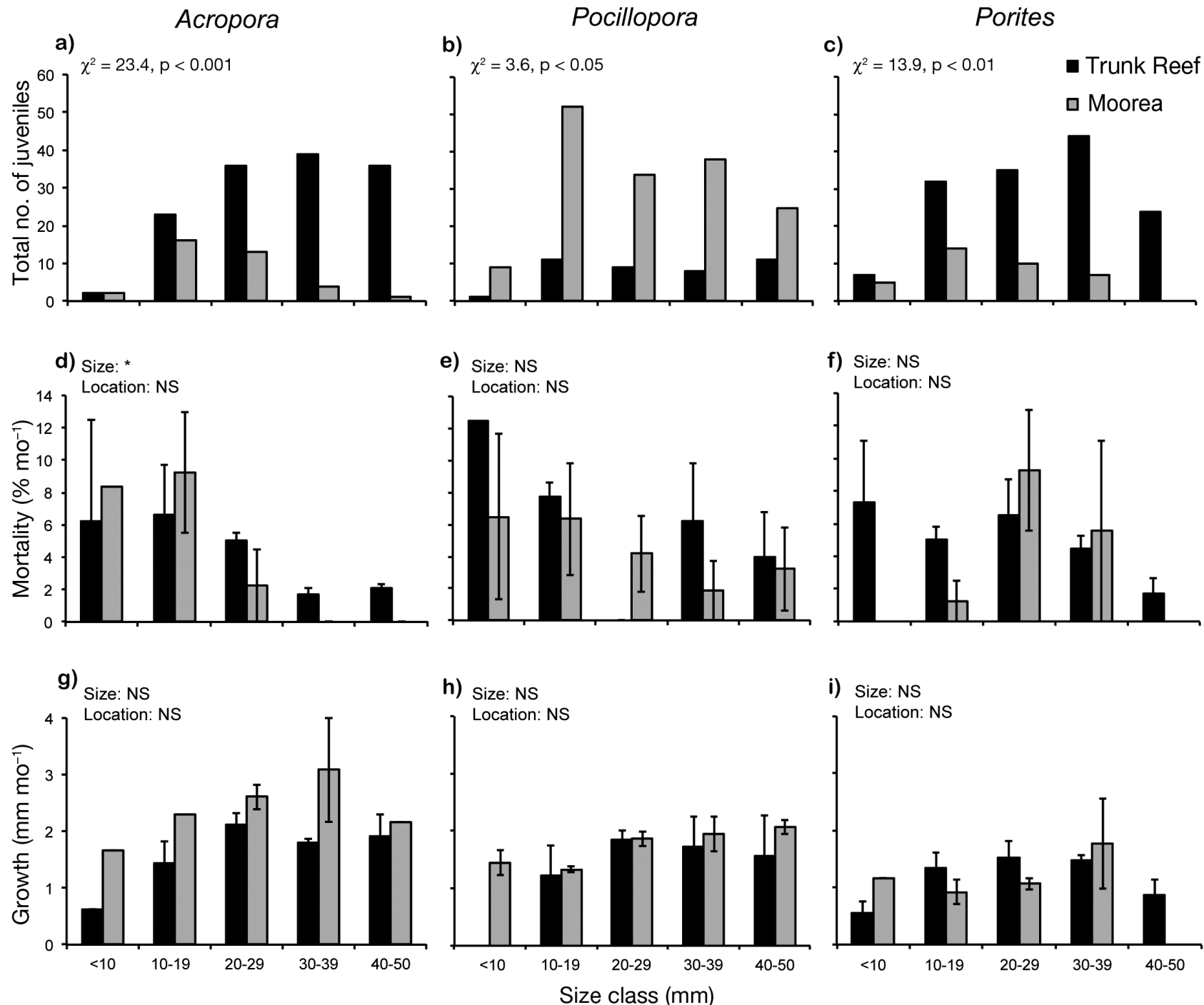

Fig. 5. Comparisons of $(\mathrm{a}-\mathrm{c})$ size structure, $(\mathrm{d}-\mathrm{f})$ mortality, and $(\mathrm{g}-\mathrm{i})$ growth of juvenile corals among 5 size classes and between locations (Trunk Reef, 347 juveniles; Moorea, 296 juveniles), for the 3 numerically dominant taxa (Acropora, Pocillopora and Porites). Significance $\left({ }^{*} \mathrm{p}<0.05\right.$, or NS $=$ not significant) is shown for the factors 'Size class' and 'Location'. Error bars represent $\pm \mathrm{SE}$

juvenile corals, with mortality decreasing with increasing size, but only for juvenile Acropora corals. Mortality also tended to be higher within the smaller size classes for juvenile Pocillopora; however, high variation in mortality estimates within size classes precluded the detection of any differences between size classes. This variation in mortality among juvenile coral taxa is difficult to explain, but may be related to the higher growth rates of Acropora compared to Pocillopora and Porites corals, enabling them a faster 'escape in size'. Bak \& Meesters (1998) suggested that once corals reach a certain size $(\sim 5 \mathrm{~mm})$, they may be afforded a size refuge (Babcock \& Mundy 1996), especially from incidental grazing by parrotfishes (Penin et al. 2010, Doropoulos et al. 2012).
Although there were no detectable differences in the density, mortality and growth of juvenile corals between Moorea and Trunk Reef, there was significant variation among sites within each reef. In general, the density of juvenile corals was lower and growth and mortality higher at exposed sites compared to the sheltered sites in both locations. For example, the exposed site on Moorea, Haapiti, had fewer juvenile corals (3.80 ind. $\mathrm{m}^{-2}$ ) than Tiahura and Vaipahu (7.47 and 8.46 ind. $\mathrm{m}^{-2}$ respectively). Similar variation in abundance of juvenile corals has been reported at these sites previously (Adjeroud et al. 2007, Penin et al. 2007), and may be related to the differential mortality among sites, as juvenile corals at Haapiti experienced 2- to 4-fold higher mortality 
Table 3. Two-factor ANOVAs comparing monthly mortality $\left(\% \mathrm{mo}^{-1}\right)$ of juveniles ( $\leq 50 \mathrm{~mm}$ ) from each main taxon, (a) Acropora, (b) Pocillopora and (c) Porites corals, among size classes $(<10,10-19,20-29,30-39$ and $40-50 \mathrm{~mm}$ ) and locations (Trunk Reef and Moorea). Significant results $(\mathrm{p}<0.05)$ are in bold

\begin{tabular}{|lccccc|}
\hline Monthly mortality & SS & df & MS & $F$ & $\mathrm{p}$ \\
\hline (a) Acropora & & & & & \\
Size class & 0.158 & 4 & 0.039 & 3.439 & $\mathbf{0 . 0 3 7}$ \\
Location & 0.012 & 1 & 0.012 & 1.076 & 0.317 \\
Size class $\times$ Location & 0.058 & 4 & 0.015 & 1.273 & 0.327 \\
& & & & & \\
(b) Pocillopora & & & & & \\
Size class & 0.136 & 4 & 0.034 & 1.69 & 0.196 \\
Location & 0.009 & 1 & 0.009 & 0.442 & 0.515 \\
Size class $\times$ Location & 0.085 & 4 & 0.021 & 1.056 & 0.407 \\
& & & & & \\
(c) Porites & & & & & \\
Size class & 0.167 & 4 & 0.042 & 2.153 & 0.116 \\
Location & $7.74 \times 10^{-5}$ & 1 & $7.74 \times 10^{-5}$ & 0.004 & 0.950 \\
Size class $\times$ Location & 0.06 & 3 & 0.02 & 1.032 & 0.402 \\
\hline
\end{tabular}

Table 4. Two-factor ANOVAs comparing monthly growth $\left(\mathrm{mm} \mathrm{mo}^{-1}\right)$ of juveniles ( $\leq 50 \mathrm{~mm}$ ) from each main taxon, (a) Acropora, (b) Pocillopora and (c) Porites corals, among size classes $(<10,10-19,20-29$, 30-39 and 40-50 mm) and locations (Trunk Reef and Moorea). Note that the 2 largest size classes (30-39 and 40-50 $\mathrm{mm}$ ) were pooled for juvenile Porites, and the 2 smallest size classes $(0-<10$ and $10-19 \mathrm{~mm}$ ) were pooled for juvenile Pocillopora

\begin{tabular}{|lccccc|}
\hline Monthly mortality & SS & df & MS & $F$ & $p$ \\
\hline (a) Acropora & & & & & \\
Size class & 3.851 & 4 & 0.963 & 0.589 & 0.671 \\
Location & 2.997 & 1 & 2.997 & 1.832 & 0.179 \\
Size class $\times$ Location & 0.726 & 4 & 0.181 & 0.111 & 0.978 \\
& & & & & \\
(b) Pocillopora & & & & & \\
Size class & 4.096 & 3 & 1.365 & 1.504 & 0.216 \\
Location & 3.155 & 1 & 3.155 & 3.474 & 0.064 \\
Size class $\times$ Location & 1.932 & 3 & 0.644 & 0.709 & 0.548 \\
& & & & & \\
(c) Porites & & & & & \\
Size class & 0.916 & 3 & 0.305 & 0.288 & 0.834 \\
Location & 0.014 & 1 & 0.014 & 0.013 & 0.908 \\
Size class $\times$ Location & 1.800 & 3 & 0.600 & 0.567 & 0.638 \\
\hline
\end{tabular}

than Tiahura and Vaipahu. Similarly, on Trunk Reef, the density of juvenile corals was lower and mortality rates 1.5-fold higher on the exposed sites (South and East) than the sheltered site (West). The mechanistic basis for these patterns is difficult to determine, but may be related to variation in environmental conditions. For example, turbulent flows reduce the settle- ment of temperate macroalgae by reducing the delivery of larvae to the substratum and increasing rates of detachment (Taylor et al. 2010), and these may have similar effect on the delivery and settlement of coral larvae. Increased wave energy at exposed sites may also lead to sediment scouring of the colonies by increasing sediment re-suspension in the water column (Bak \& Engel 1979, Babcock \& Smith 2002).

Realised growth rates (i.e. including colonies that both increased and decreased in diameter) did not differ between Trunk Reef and Moorea (mean of 1.55 and $1.57 \mathrm{~mm}$ $\mathrm{mo}^{-1}$ respectively), and were comparable to previous estimates of both Indo-Pacific and Caribbean corals (see Babcock et al. 2003). Moreover, realised and potential growth rates were not significantly different, with only 23 out of 468 juvenile colonies experiencing partial mortality, as evidenced by a decrease in size. As damage inflicted to juvenile corals is often as large as the size of the colony, they are more likely to suffer total, rather than partial, mortality (Hughes \& Jackson 1980, Meesters et al. 1997). Interestingly growth rates of juvenile corals were greatest on exposed sites within each location, coinciding with sites of highest mortality. Favourable conditions for the growth of juvenile corals may not necessarily be favourable for the survival of juvenile corals (Glassom \& Chadwick 2006). For example, the higher water flow and productivity of exposed sites may enhance coral growth (Sebens et al. 2003), but may also contribute to increased mortality through physical damage, abrasion, or associated fish communities.

Together with the variation in density, growth and mortality, the taxonomic composition of juvenile corals also differed among locations and sites. Overall, Pocillopora dominated the juvenile coral assemblage on Moorea (53.4\%), while Acropora and Porites were the dominant genera on Trunk Reef $(39.2 \%$ and $40.9 \%$, respectively. The low abundances of both adult and juvenile Acropora in Moorea is largely attributable to the high frequency and severity of acute disturbances. In shallow exposed reef environments, disturbances such as storms (Birkeland et al. 1981, Maida et al. 1994), bleaching related to increases in sea surface temper- 


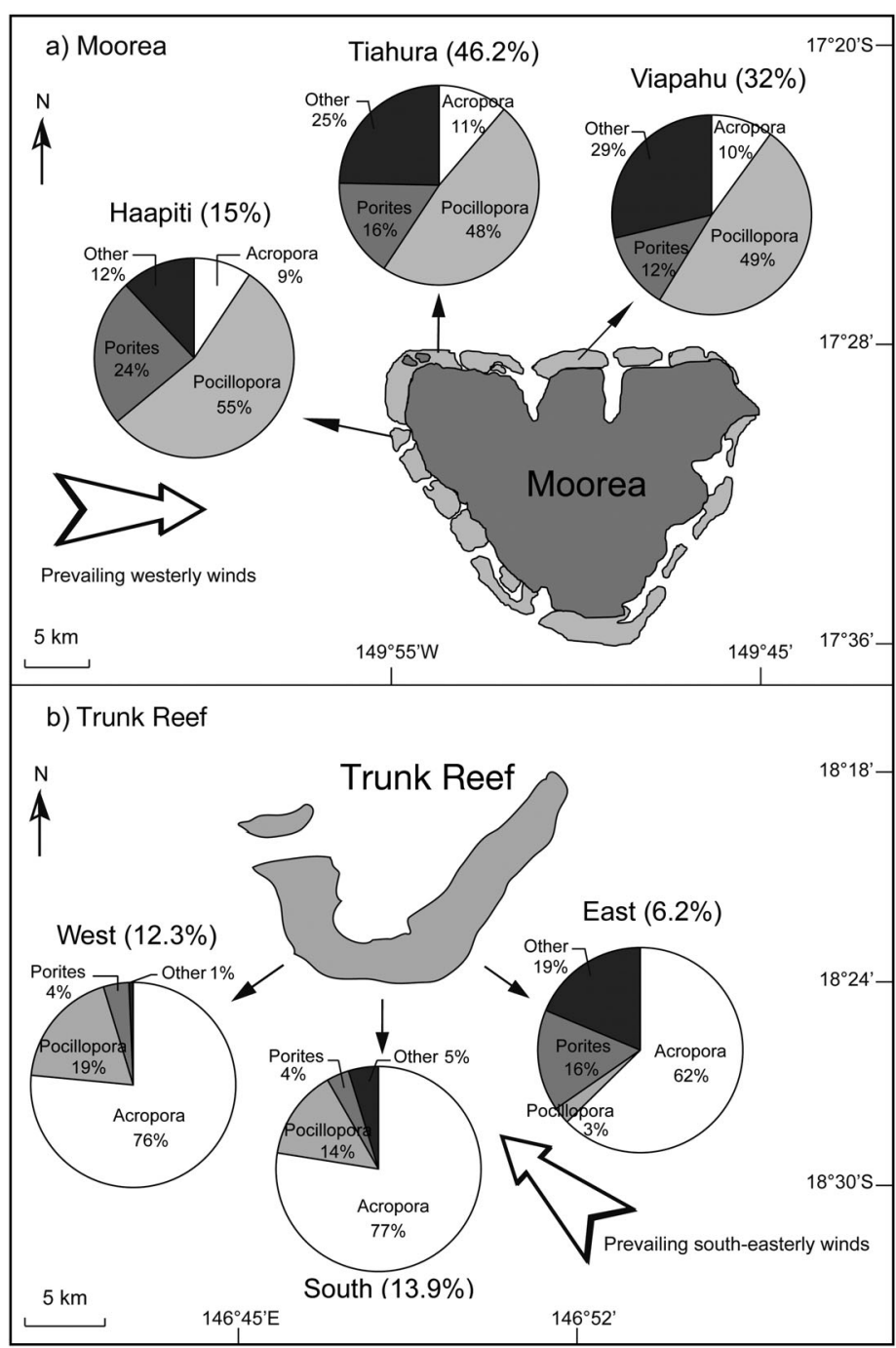

Fig. 6. Map of (a) Moorea, French Polynesia and (b) Trunk Reef, central Great Barrier Reef, showing the location of the study sites and the taxonomic composition of adult scleractinian corals at each site. Numbers in parentheses are the total coral cover (\%) at each site. The direction of prevailing trade winds at each location is indicated (white arrow). The main genera are Acropora, Pocillopora and Porites corals, and other genera are pooled together

ature, sedimentation (Gilmour 1999), and terrestrial runoff (Dubinsky \& Stambler 1996) are frequent and can greatly influence taxonomic variation in mortality rates and further augment taxonomic differences in the juvenile and ultimately in the adult assemblages over region/oceanic scales. For example, Acropora spp. are very susceptible to breakage from cyclones, climate-induced coral bleaching, as well as predation by the corallivorous sea star Acanthaster planci (Pratchett 2010). At Moorea, recurrent disturbances over the last 3 decades have led to the gradual replacement of Acropora with other genera in Moorea (Berumen \& Pratchett 2006, Pratchett et al. 2011, Trapon et al. 2011). Moreover, the low abundances of large juvenile (i.e. $30-50 \mathrm{~mm}$ diameter) Acropora and Porites may also reflect the recent disturbance history of this location, with mortality of adult corals leading to reduced larval supply and consequently fewer juvenile corals (Gilmour et al. 2013). At Trunk Reef, however, high levels of coral loss Table 5. Relationship between density of juvenile corals and cover of adult corals on Moorea and Trunk Reef. Pearson's correlation coefficients (r) are given for correlations for all coral taxa collectively (i.e. total coral cover vs. total juvenile density), and the 3 most abundant genera independently (e.g. Acropora cover vs. juvenile Acropora density). Correlations are based on the cover of adult corals and the mean density of juvenile corals per transect $(n=9)$. Significant results $(p<0.05)$ are in bold

\begin{tabular}{|lrc|}
\hline & $\mathrm{r}$ & $\mathrm{p}$ \\
\hline Moorea & & \\
Total corals & 0.795 & $\mathbf{0 . 0 1 0}$ \\
Acropora & -0.139 & 0.721 \\
Pocillopora & 0.567 & 0.111 \\
Porites & -0.207 & 0.594 \\
Trunk Reef & & \\
Total corals & 0.338 & 0.374 \\
Acropora & -0.166 & 0.669 \\
Pocillopora & -0.299 & 0.434 \\
Porites & 0.663 & 0.052 \\
\hline
\end{tabular}
in 2001/2002 have been followed by an extended period without any major disturbances, enabling the rapid recovery of corals, especially Acropora (Pratchett et al. 2009).

Superimposed upon marked regional variation in the composition of juvenile coral assemblages, there were significant differences in the relative abundance of taxa, especially on Moorea. On Moorea, the abundances of each taxon of juvenile corals was lowest at the exposed site, Haapiti, with the reductions being most pronounced in Acropora and Porites. Consequently, the relative abundance of juvenile Pocillopora was much higher at Haapiti than at Tiahura and Vaipahu. Pocillopora may be able to colonise the frequently disturbed environment of Haapiti faster than Acropora and Porites, which may need longer residence times and lower flushing rates for planula to settle on the substratum (Sammarco \& Andrews 1988). In contrast, there was little variation in the rel- 

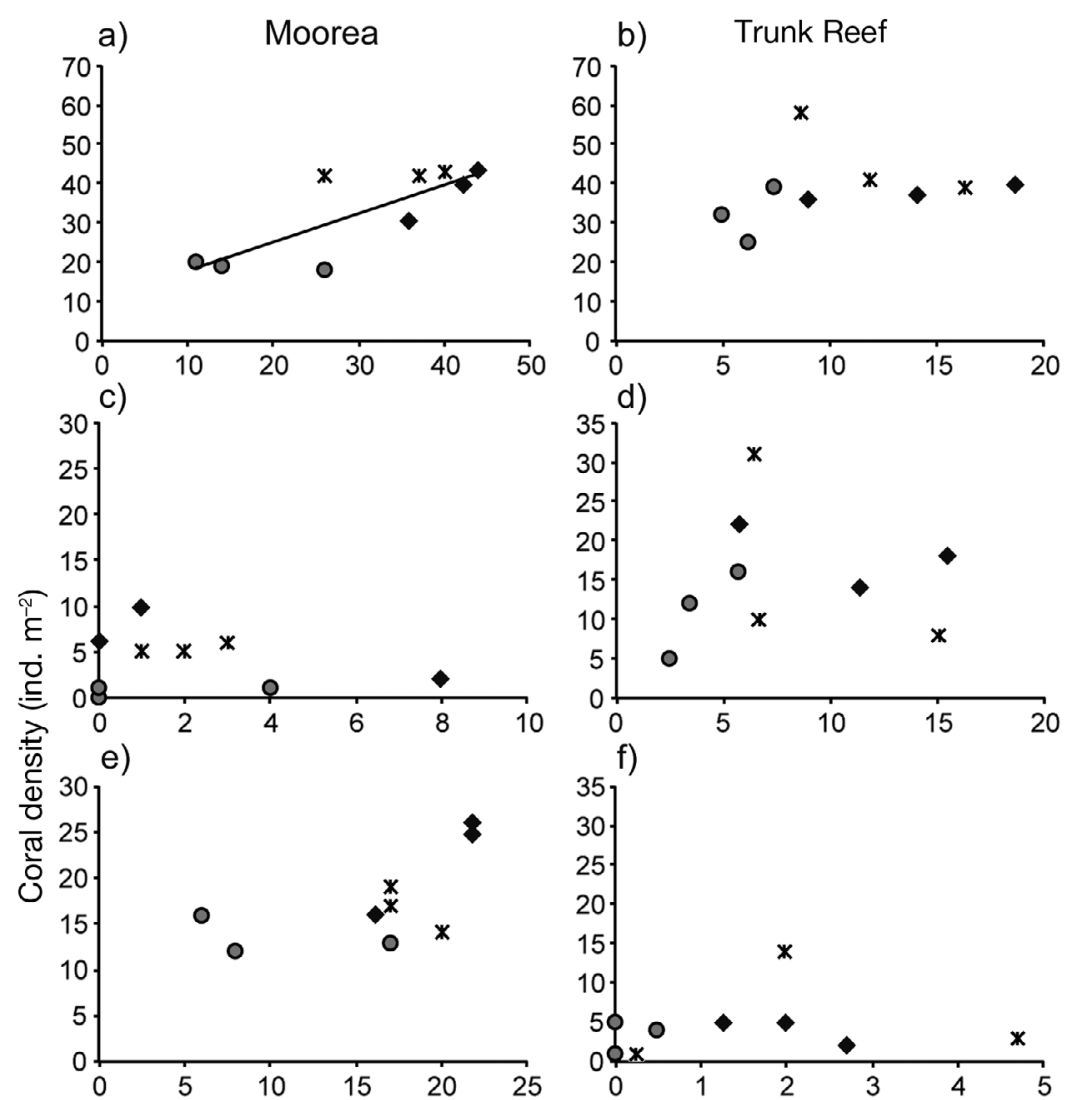

g)

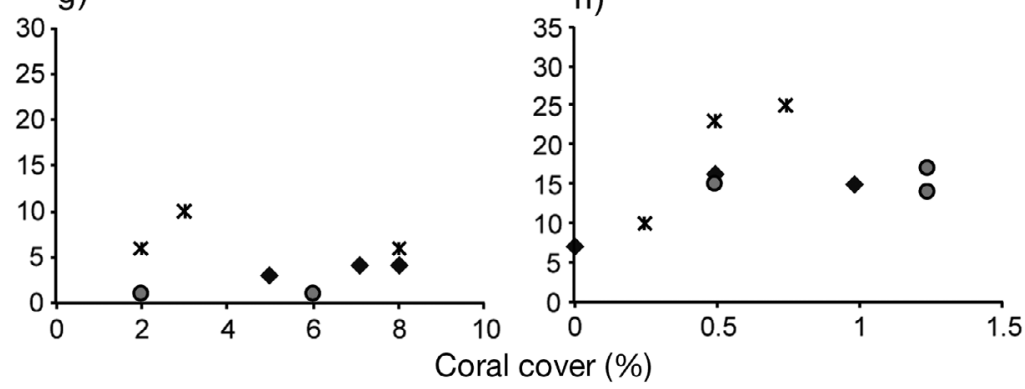

Fig. 7. Relationship between juvenile coral densities and adult coral cover on the reef crest of Moorea and Trunk Reef, for $(\mathrm{a}, \mathrm{b})$ total corals, $(\mathrm{c}, \mathrm{d})$ Acropora, $(\mathrm{e}, \mathrm{f})$ Pocillopora and $(\mathrm{g}, \mathrm{h})$ Porites. Analyses are based on adult coral cover and mean density of juvenile corals per transect ( $\mathrm{n}=9$ for each location). The 3 symbols represent the 3 sites at each location: Haapiti in Moorea or East site at Trunk Reef $(\bigcirc)$, Tiahura in Moorea or South site at Trunk Reef $(\bullet)$, and Vaipahu in Moorea or West site at Trunk Reef $(\boldsymbol{*})$. The solid line (a) represents a significant correlation

ative abundance of Pocillopora among sites on Trunk Reef, and this may be related to geographical differences in their major reproductive mode. The dominant species of Pocillopora in Moorea (Pocillopora meandrina and Pocillopora verrucosa) are broadcast spawners (Penin et al. 2007), whereas the dominant species on Trunk Reef (Pocillopora damicornis) is a brooder.
The present study revealed marked within-reef variation in the overall density, mortality and growth rates of juvenile corals, whereas differences at the larger geographic scale were mostly related to differences in the composition of juvenile and adult coral assemblages. Interestingly, there were no significant differences in the density of juvenile corals between Moorea and Trunk Reef, despite adult coral cover being 3-fold higher on Moorea compared to Trunk Reef. This suggests that contemporary adult coral assemblages are structured more by differential adult mortality, larval settlement, or very early post-settlement mortality (before colonies can be observed in situ), rather than juvenile growth and mortality. Both Trunk Reef and Moorea have been subject to coral bleaching and outbreaks of Acanthaster planci, which have caused high levels of coral mortality since 2002 (Pratchett et al. 2009, Trapon et al. 2011). There may have also been changes in settlement rates since initial surveys suggested they were much lower at Moorea than in the central GBR (Adjeroud et al. 2007), but there have not been any recent studies of coral settlement rates at these locations. Further studies are clearly necessary to elucidate the relative importance of larval supply and settlement, and early post-settlement mortality in shaping juvenile and ultimately adult coral assemblages in different locations. Importantly, the vulnerability and resilience of coral assemblages in different geographical regions will require an understanding and integration of key demographic processes across multiple life stages.
Acknowledgements. We thank the staff of the Orpheus Island Research Station and the Gump Field Station for field and logistical support, and M. Berumen, L. Penin, C. Pisapia and D. Pratchett for field assistance. Field sampling on the GBR was funded by the Australian Research Council and the Great Barrier Reef Marine Park Authority, while research in French Polynesia was supported by Total Corporation and the French Ministry for Science. 


\section{LITERATURE CITED}

Adam TC, Schmitt RJ, Holbrook SJ, Brooks AJ, Edmunds PJ, Carpenter RC, Bernardi G (2011) Herbivory, connectivity, and ecosystem resilience: response of a coral reef to a large-scale perturbation. PLoS ONE 6:e23717

Adjeroud M, Penin L, Carroll A (2007) Spatio-temporal heterogeneity in coral recruitment around Moorea, French Polynesia: implications for population maintenance. J Exp Mar Biol Ecol 341:204-218

Babcock RC (1985) Growth and mortality in juvenile corals (Goniastrea, Platygyra and Acropora) in the first year. Proc 5th Int Coral Reef Symp 4:355-360

Babcock RC, Mundy CP (1996) Coral recruitment: consequences of settlement choice for early growth and survivorship in two scleractinians. J Exp Mar Biol Ecol 206: 179-201

Babcock RC, Smith L (2002) Effects of sedimentation on coral settlement and survivorship. Proc 9th Int Coral Reef Symp 1:245-248

Babcock RC, Baird AH, Piromvaragorn S, Thomson DP, Willis BL (2003) Identification of scleractinian coral recruits from Indo-Pacific reefs. Zool Stud 42:211-226

Baird AH, Hughes TP (1997) Spatial variation in coral recruitment around Lizard Island, Australia. Proc 8th Int Coral Reef Symp 2:1207-1210

> Bak RPM, Engel MS (1979) Distribution, abundance and survival of juvenile hermatypic corals (Scleractinia) and the importance of life-history strategies in the parent coral community. Mar Biol 54:341-352

> Bak RPM, Meesters EH (1998) Coral population structure: the hidden information of colony size-frequency distributions. Mar Ecol Prog Ser 162:301-306

Bellwood DR, Hoey AS, Choat JH (2003) Limited functional redundancy in high diversity systems: resilience and ecosystem function on coral reefs. Ecol Lett 6:281-285

Bellwood DR, Hoey AS, Hughes TP (2012) Human activity selectively impacts the ecosystem roles of parrotfishes on coral reefs. Proc R Soc B 279:1621-1629

Berumen ML, Pratchett MS (2006) Recovery without resilience: persistent disturbance and long-term shifts in the structure of fish and coral communities at Tiahura Reef, Moorea. Coral Reefs 25:647-653

Birkeland C, Rowley D, Randall RH (1981) Coral recruitment patterns at Guam. Proc 4th Int Coral Reef Symp 2: 339-344

- Box SJ, Mumby PJ (2007) Effect of macroalgal competition on growth and survival of juvenile Caribbean corals. Mar Ecol Prog Ser 342:139-149

> Caley MJ, Carr MH, Hixon MA, Hughes TP, Jones GP, Menge BA (1996) Recruitment and the local dynamics of open marine populations. Annu Rev Ecol Syst 27: 477-500

Connell JH, Hughes TP, Wallace CC (1997) A 30-year study of coral abundance, recruitment, and disturbance at several scales in space and time. Ecol Monogr 67:461-488

Connolly SR, Hughes TP, Bellwood DR, Karlson RH (2005) Community structure of corals and reef fishes at multiple scales. Science 309:1363-1365

> Cornell HV, Karlson RH, Hughes TP (2007) Scale-dependent variation in coral community similarity across sites, islands, and island groups. Ecology 88:1707-1715

> Cowen RK, Sponaugle S (2009) Larval dispersal and marine population connectivity. Annu Rev Mar Sci 1:443-466

> Doropoulos C, Ward S, Marshell A, Diaz-Pulido G, Mumby
PJ (2012) Interaction among chronic and acute impacts on coral recruits: the importance of size-escape thresholds. Ecology 93:2131-2138

> Dubinsky ZVY, Stambler N (1996) Marine pollution and coral reefs. Glob Change Biol 2:511-526

Edmunds PJ (2000) Patterns in the distribution of juvenile corals and coral reef community structure in St. John, US Virgin Islands. Mar Ecol Prog Ser 202:113-124

Edmunds PJ (2007) Evidence for a decadal-scale decline in the growth rates of juvenile scleractinian corals. Mar Ecol Prog Ser 341:1-13

> Fisk DA, Harriott VJ (1990) Spatial and temporal variation in coral recruitment on the Great Barrier Reef: implications for dispersal hypotheses. Mar Biol 107:485-490

- Gilmour J (1999) Experimental investigation into the effects of suspended sediment on fertilisation, larval survival and settlement in a scleractinian coral. Mar Biol 135: 451-462

Gilmour JP, Smith LD, Heyward AJ, Baird AH, Pratchett MS (2013) Recovery of an isolated coral reef system following severe disturbance. Science 340:69-71

Glassom D, Chadwick NE (2006) Recruitment, growth and mortality of juvenile corals at Eilat, northern Red Sea. Mar Ecol Prog Ser 318:111-122

> Harriott VJ (1983) Reproductive seasonality, settlement, and post-settlement mortality of Pocillopora damicornis (Linnaeus), at Lizard Island, Great Barrier Reef. Coral Reefs 2:151-157

Hixon MA, Carr MH (1997) Synergistic predation, density dependence, and population regulation in marine fish. Science 277:946-949

Hoey AS, Bellwood DR (2008) Cross-shelf variation in the role of parrotfishes on the Great Barrier Reef. Coral Reefs $27: 37-47$

Hoey AS, Pratchett MS, Cvitanovic C (2011) High macroalgal cover and low coral recruitment undermines the potential resilience of the world's southermost coral reef assemblages. PLoS ONE 6:e25824

Hughes TP (1990) Recruitment limitation, mortality, and population regulation in open systems: a case study. Ecology 71:12-20

Hughes TP, Jackson JBC (1980) Do corals lie about their age? Some demographic consequences of partial mortality, fission, and fusion. Science 209:713-715

> Hughes TP, Baird AH, Dinsdale EA, Moltschaniwskyj NA, Pratchett MS, Tanner JE, Willis BL (1999) Patterns of recruitment and abundance of corals along the Great Barrier Reef. Nature 397:59-63

Hughes TP, Baird AH, Dinsdale EA, Moltschaniwskyj NA, Pratchett MS, Tanner JE, Willis BL (2000) Supply-side ecology works both ways: the link between benthic adults, fecundity, and larval recruits. Ecology 81:2241-2249

$>$ Hughes TP, Baird AH, Dinsdale EA, Harriott VJ and others (2002) Detecting regional variation using meta-analysis and large-scale sampling: latitudinal patterns in recruitment. Ecology 83:436-451

Hughes TP, Baird AH, Dinsdale EA, Moltschaniwskyj NA, Pratchett MS, Tanner JE, Willis BL (2012) Assembly rules of reef corals are flexible along a steep climatic gradient. Curr Biol 22:736-741

- Kayal M, Vercelloni J, Lison de Loma T, Bosserelle P and others (2012) Predator crown-of-thorns starfish (Acanthaster planci) outbreak, mass mortality of corals, and cascading effects on reef fish and benthic communities. PLoS ONE 7:e47363 
Linares C, Pratchett MS, Coker DJ (2011) Recolonisation of Acropora hyacinthus following climate-induced coral bleaching on the Great Barrier Reef. Mar Ecol Prog Ser 438:97-104

Maida M, Coll JC, Sammarco PW (1994) Shedding new light on scleractinian coral recruitment. J Exp Mar Biol Ecol 180:189-202

- Meesters EH, Wesseling I, Bak RPM (1997) Coral colony tissue damage in six species of reef-building corals: partial mortality in relation with depth and surface area. J Sea Res 37:131-144

Miller MW, Weil E, Szmant AM (2000) Coral recruitment and juvenile mortality as structuring factors for reef benthic communities in Biscayne National Park, USA. Coral Reefs 19:115-123

Mundy C, Babcock R (2000) Are vertical distribution patterns of scleractinian corals maintained by pre- or postsettlement processes? A case study of three contrasting species. Mar Ecol Prog Ser 198:109-119

Penin L, Adjeroud M, Pratchett MS, Hughes TP (2007) Spatial distribution of juvenile and adult corals around Moorea (French Polynesia): implications for population regulation. Bull Mar Sci 80:379-389

Penin L, Michonneau F, Baird AH, Connolly SR, Pratchett MS, Kayal M, Adjeroud M (2010) Early post-settlement mortality and the structure of coral assemblages. Mar Ecol Prog Ser 408:55-64

$>$ Penin L, Michonneau F, Carroll A, Adjeroud M (2011) Effects of predators and grazers exclusion on early postsettlement coral mortality. Hydrobiologia 663:259-264

Pratchett MS (2010) Changes in coral assemblages during an outbreak of Acanthaster planci at Lizard Island, northern Great Barrier Reef (1995-1999). Coral Reefs 29: 717-725

Pratchett MS, Wilson SK, Baird AH (2006) Declines in the abundance of Chaetodon butterflyfishes following extensive coral depletion. J Fish Biol 69:1269-1280

Pratchett MS, Baird AH, McCowan DM, Coker DJ, Cole AJ, Wilson SK (2009) Protracted declines in coral cover and fish abundance following climate-induced coral bleaching on the Great Barrier Reef. Proc 11th Int Coral Reef Symp 1:1042-1046

Pratchett MS, Trapon M, Berumen ML, Chong-Seng K (2011) Recent disturbances augment community shifts in coral assemblages in Moorea, French Polynesia. Coral Reefs 30:183-193

Ritson-Williams R, Arnold SN, Fogarty ND, Steneck RS, Ver-

Editorial responsibility: Peter Edmunds,

Northridge, California, USA meij MJA, Paul VL (2009) New perspectives on ecological mechanisms affecting coral recruitment on reefs. Smithson Contrib Mar Sci 38:437-457

- Roff G, Mumby PJ (2012) Global disparity in the resilience of coral reefs. Trends Ecol Evol 27:404-413

Rotjan RD, Lewis SM (2008) Impact of coral predators on tropical reefs. Mar Ecol Prog Ser 367:73-91

Ruiz-Zárate MA, Arias-González JE (2004) Spatial study of juvenile corals in the northern region of the Mesoamerican Barrier Reef System (MBRS). Coral Reefs 23: 584-594

Rylaarsdam KW (1983) Life histories and abundance patterns of colonial corals on Jamaican reefs. Mar Ecol Prog Ser 13:249-260

Sammarco PW (1985) The Great Barrier Reef vs. the Caribbean: comparison of grazers, coral recruitment patterns and reef recovery. Proc 5th Int Coral Reef Symp 4: 391-398

> Sammarco PW, Andrews JC (1988) Localized dispersal and recruitment in Great Barrier Reef corals: the Helix experiment. Science 239:1422-1424

Sebens KP, Helmuth B, Carrington E, Agius B (2003) Effects of water flow on growth and energetics of the scleractinian coral Agaricia tenuifolia in Belize. Coral Reefs 22: $35-47$

Taylor D, Delaux S, Stevens C, Nokes R, Schiel D (2010) Settlement rates of macroalgal propagules: cross-species comparisons in a turbulent environment. Limnol Oceanogr 55:66-76

- Trapon ML, Pratchett MS, Penin L (2011) Comparative effects of different disturbances in coral reef habitats in Moorea, French Polynesia. J Mar Biol 2011:807625

> Trapon ML, Pratchett MS, Hoey AS (2013) Spatial variation in abundance, size and orientation of juvenile corals related to the biomass of parrotfishes on the Great Barrier Reef, Australia. PLoS ONE 8:e57788

> Vermeij MJA, Sandin SA (2008) Density-dependent settlement and mortality structure the earliest life phases of a coral population. Ecology 89:1994-2004

- Weersing K, Toonen RJ (2009) Population genetics, larval dispersal, and connectivity in marine systems. Mar Ecol Prog Ser 393:1-12

Wilkinson CR (2004) Status of coral reefs of the world: 2004. Australian Institute of Marine Science, Townsville

> Wilson JR, Harrison PL (2005) Post-settlement mortality and growth of newly settled reef corals in a subtropical environment. Coral Reefs 24:418-421

Submitted: October 30, 2012; Accepted: April 27, 2013

Proofs received from author(s): July 10, 2013 